\title{
Pat Carney and the Dismantling of the National Energy Program
}

\section{Tammy Nemeth}

\begin{abstract}
The Progressive Conservative energy policy initiative of 1984-1985 represented a distinct change not only in how policy was formulated but also in the party's vision of Canada. The Tories endeavoured to decentralize government, encourage cooperative federal-provincial relations, and develop an energy policy outside the bureaucracy through consultation with the oil industry. Patricia Carney played a vital role first as opposition energy critic and then as minister of Energy, Mines and Resources. She emphasized consultation and cooperation with industry and the provinces and accepted most of their input uncritically. These developments are explored through an examination of the policy-making process developed by the Conservatives in opposition, and then put into practice after they took power in 1984.
\end{abstract}

Tuesday, 4 September 1984 ushered in a dramatic change in Canadian politics when the Progressive Conservative party (or PCs), headed by Brian Mulroney, won an overwhelming majority in the federal election. The PCs captured 211 seats out of a possible 282 with 58 of those seats located in Western Canada.' Although the PCs did not make energy the focus of the 1984 election campaign, energy policy was certainly a priority before, during and after the election. While in opposition from 1980 to 1984 most of the strong and consistent Conservative support was from Western Canada, representing 52 out of the total 101 PC seats. Western Canadians believed that the Liberal party's National Energy Program (NEP) discriminated against them, and the oil and gas industry viewed the NEP as an unnecessary government intrusion into their business: both interests wanted the NEP dismantled. ${ }^{2}$ After Mulroney was elected as leader of the opposition in the spring of 1983, he appointed Patricia (Pat) Carney as opposition

Past Imperfect, Vol. 7, 1998, pp.87-123 
energy critic. Her task was to develop a Canadian energy policy that would dismantle and replace the NEP.

This essay will investigate how the PC party, under Mulroney, formulated the energy policy that led to the dismantling of the NEP. In this case it is necessary to approach the policy-making process through the experiences and actions of Carney rather than Mulroney or the bureaucracy in Energy, Mines and Resources (EMR). Although the Progressive Conservatives would have dismantled the NEP without her, the manner in which the basic principles and policies were developed and the final content of the agreements with the producing provinces were a direct result of Carney's personal influence. The importance of an individual, other than the prime minister, and his or her influence on events cannot be underestimated or overlooked because in "energy politics, ideas are central and personalities, egos and reputations are rampant." Thus, the analysis of the PC policy-making process will focus on three elements: first, Carney and the energy policy platform that she formulated while in opposition; second, the extent that the PCs' opposition energy platform was incorporated into government policy when they assumed power; and finally, the examination of how much of the policy was influenced by ideology and the extent of industry and provincial influence.

The PC policy-making process between 1983 and 1985 represented a significant change from the Liberal party's methods of the 1970s and 1980s. Where the Liberals were confrontational towards industry and provincial governments, the Mulroney-led Conservatives were consultative; their election gave Ottawa a new opportunity, a chance to bring new solutions to old problems. The process for PC energy policy formulation reflected these objectives. Carney, the key political player in these developments, looked to industry rather than the government bureaucracy for leadership. She wanted a 
policy that would stimulate economic growth, heal the rift between the provinces and Ottawa through the recognition of regional interests, and benefit all Canadians.

Since the massive oil find at Leduc in 1947 Canadian energy policy experienced several changes. In the years between 1947 and 1971 the main priority was the development and expansion of Canadian oil and gas: Ottawa did not interfere to any great degree with the operations of the oil industry or the policies of the provincial governments. ${ }^{4}$ The economy of Alberta grew and relations between the provincial and federal governments were largely cordial and cooperative. Unfortunately, in the 1970 s and early $1980 \mathrm{~s}$, the relationship between the federal government and the oil industry and between Ottawa and Alberta deteriorated in an atmosphere of crisis and conflict.

When the oil crisis hit in 1973 the Liberal government attempted to develop an energy policy that would redirect the control of the industry toward the federal government and away from the producing provinces. The confrontation between Ottawa and Alberta escalated when the federal government, with little consultation with either the province or the industry, kept the domestic price of Alberta oil much lower than the world price. As well, it initiated changes to the income tax system that penalized both Alberta and the oil industry. Although lower prices for oil were to benefit all Canadians, most of the consumers were in Central Canada, thus Ottawa's actions were perceived in the West, and particularly in Alberta, as a way to curtail the economic prosperity of a region outside the traditional centre of economic and political power.'s Eventually, an agreement was reached between Alberta and Ottawa regarding the sharing of windfall profits which generated a brief respite in the deterioration of the federal-provincial relationship. 
The Liberals were narrowly defeated in the 1979 election and the brief Progressive Conservative government under Joe Clark had to deal with the second oil crisis which occurred that same year. Clark's minority government, which had strong representation from the West, assumed that it would be able to continue to protect Canadian consumers as well as reach a quick accord with Alberta on pricing and revenue sharing. However, the federal government was unsuccessful in negotiating an acceptable agreement with the government of Alberta despite the fact that the minister of EMR was a Westerner.6 After only 200 days in power, the PC budget, which contained a sizeable gasoline tax, was defeated in the House of Commons on a non-confidence vote; an election was called and Pierre Elliott Trudeau and the Liberals were returned to office.?

The election of Trudeau's majority Liberal government in February 1980 marked a turning point in the history of Canadian energy policy. In 1980, oil prices were at an all time high.' In keeping with the policy put in place during the first energy crisis, the Canadian government sanctioned subsidized imported oil for Eastern Canada so that the region would pay the same price as the area west of the Ottawa River which relied on cheaper Canadian oil. Therefore, Alberta was forced to sell its oil domestically at an average price of $\$ 15.75$ per barrel, about 40 percent of the world price." The federal government believed that it needed to take some kind of action that would not only protect the consumer but would also provide more revenue for the federal government to finance its energy initiatives. The task was left to Marc Lalonde who was appointed minister of EMR.

He was at the centre of the Liberal energy policy-making process and he considered the NEP to be his brainchild, however, "Lalonde's ambitious plan meshed closely with that of the seventy-odd economists whom Ed Clark [the 
senior assistant deputy minister for policy in EMR] had forged into an impressive analytical team at EMR." 10 The result was that on 28 October 1980 Finance Minister Allan MacEachen delivered the budget which contained Lalonde's National Energy Program. There had been little or no consultation with the provinces and industry during the formulation of the NEP and because it was announced in the budget, it was shrouded in secrecy." Ultimately, the program had been formulated by a small group of bureaucrats who were helped by Lalonde. Relations between Alberta and Ottawa and the industry and Ottawa were soured once again when the details of the NEP were announced.

The primary goal of the NEP was to achieve energy self-sufficiency in Canada by 1990 . Energy security was to be achieved by increasing Canadian ownership and participation in the oil and gas industry, finding new sources of Canadian oil and gas, and increasing the federal share of oil and gas revenues. The program introduced several new taxes, rules and regulations, such as the Petroleum Compensation Charge (PCC) which was levied on domestic refiners to pay for the Oil Import Compensation Program (OICP). The oICP was a federal subsidy designed for refiners who processed imported oil in order to reduce their costs to the same level as refiners who processed Canadian oil." There was also the Natural Gas and Gas Liquids Tax (NGGLT). This tax was applied to all natural gas and gas liquids sales, or to all marketable gas in Canada. The amount or level of taxation varied depending on factors such as the transportation costs and was set to equal about 65 per cent of the average price for crude oil at the Toronto refinery gate. ${ }^{3}$

The next new tax was the Petroleum and Gas Revenue Tax (PGRT). The PGRT was quite a complex mechanism that consisted of two parts: the production revenue tax and the resource royalty tax. The former was initially set at a 
rate of eight per cent on the production revenue and the latter of a rate of eight per cent charged to every person who received any type of resource royalty. The PGRT was to be reviewed as oil prices increased and in 1982 it was actually reduced to 14.67 per cent instead of the previous 16 per cent. In addition the PGRT was not income tax deductible. ${ }^{14}$

Another tax introduced in the NEP was the Canadian Ownership Charge ( $(\mathrm{C})$ ) which was levied on "gasoline and petroleum products and gas consumers" is for the purpose of purchasing major foreign-owned oil companies by publicly-owned Canadian companies. This would in turn increase Canadian ownership and control levels in the oil industry in Canada. Funds from the coc went directly into the Canadian Ownership Account (COA), and were to be used specifically to increase Canadian public ownership of the Canadian oil and gas industry. ${ }^{16}$ However, by 1984 the federal government broadened the uses of the account to assist in financing some of the other incentive programs introduced in the NEP.

The NEP also dramatically increased the role of the federal government in the exploration and development of oil and gas in Canada. Through the Petroleum Incentive Plan (PIP) grants, it redirected exploration and development to the Canada Lands, or land which was owned and controlled by the federal government. ${ }^{17}$ The PIP grant system was developed to replace the previous system of depletion allowance and established direct incentive payments for exploration and development in Canada by Canadian taxable and non-taxable firms as well as individuals. The process of applying for PIP grants was extremely time consuming as it involved a great deal of paperwork. Moreover, the amount of money a company could receive was directly related to the exent of Canadian ownership and control in the company. In addition, the grant amount was significantly greater for exploration and 
development expenses sustained on Canada Lands than those incurred on land under provincial control.

The federal government created the Canada Oil and Gas Lands Administration (COGLA) in order to administer the Canada Oil and Gas Act (Bill C-48). The Act included objectives to ensure that Canadian taxpayers would receive a fair return on frontier oil and gas exploration and development; to encourage exploration and development on Canada Lands; and to promote the use of Canadian goods and services, as well as employment for Canadians, in frontier oil and gas activities. This legislation also provided for a 25 per cent retroactive and noncompensatory Crown share, or "back-in," in every development project on Canada Lands that was to be held by Petro-Canada or some other Crown corporation."

The Western provinces, particularly Alberta, and the oil industry were angered by the NEP and federal-provincial relations reached their lowest point. The Alberta government responded vigorously to the NEP. In three stages, it reduced oil production and shipments to Eastern Canada by 60,000 barrels per day. The province launched a court challenge to the NEP on the grounds that federal taxation on exports of provincially-owned resources was a violation of the constitution. In addition, the Alberta government withheld approval of new oil sands and heavy oil projects. ${ }^{19}$ The oil industry also reacted negatively by moving drilling rigs across the border into the United States in front of television cameras and journalists. Furthermore, in an attempt to influence the Liberal government to change the NEP, many multinational companies slashed their exploration budgets for 1981.00 The final result of the several retaliatory actions by Alberta and the oil industry was the 1981 Energy Accord, or Canada-Alberta Energy Agreement.21 The federal-provincial crisis was averted, but the oil-producing provinces and industry still wanted the NEP dismantled. By 1983 there was a recession in both 
Canada and the United States and the price of oil was in decline.

On 9 June 1983 Mulroney defeated Clark for the leadership of the Progressive Conservative party. As the new leader, Mulroney immediately began to reorganize the roles and responsibilities of the Conservative MPs. ${ }^{2}$ One of his first actions was to create a shadow cabinet, a group of opposition members appointed by the leader who mirrored the actual federal cabinet. In September 1983 Carney, a Vancouver MP, was moved from the position of finance critic to that of energy critic. ${ }^{23} \mathrm{Her}$ appointment to that position of energy critic raised some eyebrows since she was chosen over the long-time Clark supporter Harvie Andre. Andre's constituency was in Calgary and he had considerable contacts with the oil industry, but his close ties to Clark probably did not help his situation.2 Carney, on the other hand, had been co-chair at both the PC party convention and the leadership convention and therefore was in a position where she could claim neutrality because she had not supported a particular candidate; "in short, she made a lot of friends, but more importantly, no enemies."2s

Her personality, business background and personal philosophy were central to the role she played first as critic and then as minister in shaping Conservative energy policy. Carney had been a business columnist for the Vancouver Sun, and a freelance business writer for several other newspapers in the 1960 s. While working as a journalist she put herself through university, earning an economics degree. She also travelled to the Arctic and wrote several articles on oil and gas exploration and development in the Northern regions of Canada. Her articles reflected her own philosophy of the oil and gas industry: that the industry "brought new jobs, new growth" and could help to diversify the economy of the region." 
In the early 1970s Camey returned to the Northwest Territories and lived in Yellowknife for a period of time. A major issue in the North throughout the 1970s was the effect that pipeline development would have on the Northern environment and its communities. The federal government appointed a royal commission in 1974, headed by Justice Thomas Berger of British Columbia, to assess the impact of pipeline construction through the Mackenzie Valley. Anticipating a development boom, Carney and her twin brother Jim formed a consulting firm, Gemini North, to conduct socio-economic studies for the territorial governments and the oil and gas industry. Her company, composed of social anthropologists, engineers, and economists, reported in a somewhat controversial publication that pipeline development could only serve to diversify and stabilize the Northern communities. ${ }^{2}$ During this time she also completed a master's degree in regional planning and held memberships in a variety of professional organizations. ${ }^{30}$ In 1979, while she was still working in the Northern part of Canada, Carney was asked by Joe Clark to run for the PCs. She ran against a former Vancouver mayor in the riding of Vancouver Centre in the 1979 election and lost by 95 votes in a recount, but ran again in 1980 and won by over 1,500 votes.31 She held various positions while in opposition but it was not until she was given the position of energy critic in 1983 that her skills and business experience were put to efficient use. She was not only familiar with the industry and how it worked, she also believed-in line with Conservative ideology - that the oil industry would have a greater and more positive impact on the economy if there was less government intervention. ${ }^{32}$

In the fall of 1983 the opposition Priorities and Planning Committee entitled distributed "Steps in the Policy Process" to members of the shadow cabinet. This document provided a provided a time frame for each critic 
to prepare assessments of each portfolio." The assessments were then to be used to form a PC policy platform for the 1984 election. Carney's first task, then, as energy critic, was to meet with industry and provincial representatives to assess what they did or did not like about the NEP. She also met with EMR officials who provided her with a briefing book outlining the department's operations. It is important to note that the PCs in opposition, under Mulroney, were very well organized. They did not want a repeat of the situation in 1979 when they had been poorly prepared to assume office and were unable to keep several of Clark's election promises. ${ }^{34}$

The PC policy making procedure was a staged process. In a 10 November 1983 memorandum, Carney put forward several broad statements of what PC energy policy should be; she did not provide the clarity and detail found in later documents. ${ }^{\text {ss }}$ A few weeks later, a discussion paper dated December 1983 provided more detailed policy ideas very similar to statements that would be made by the Conservatives during the 1984 election campaign. ${ }^{36}$ Some of the core concepts contained in the discussion paper were: less government interference, fair treatment for producers and consumers, and recognition of the oil and gas industry as an "engine of growth" for the Canadian economy." Where had these ideas come from?

Between September and December of 1983 Carney had a number of meetings with various industry representatives, special interest groups, and many of the provincial energy ministers. There is evidence, in the transcripts from these meetings, that her policy was influenced by the people with whom she consulted. ${ }^{38}$ Nevertheless, she had a clear idea herself of what a PC energy policy should contain. The ideas of less government intervention and faimess to producers and consumers were a very clear reflection of Carney's and the party's ideology at that time. ${ }^{39}$ The idea of energy as an "engine of growth" was not a new one for 
Carney. It was also a notion widely expressed by business and political leaders in the West throughout the 1960s and 1970s. As mentioned earlier, she subscribed to this particular concept when she was a journalist for the Vancouver Sun in the 1960s.

At a private dinner meeting in Calgary with select industry representatives, Carney outlined the political dimensions of an emerging Conservative energy policy, and told those present "ignore [the] political implications; just feed us policies, politics is our job." "to In keeping with the strategy to design a comprehensive PC energy policy that would combine both political statements and specific policies, she decided to appoint six industry task forces, or study groups, to look at five aspects of the NEP.41 The five aspects were: Price/Taxation/Revenue Sharing, PIP grants, Cogla operations, Oil Sands and Heavy Oil Development, and Natural Gas Policy.

On 18 January 1984, Carney sent letters out to the prospective study group members. ${ }^{42}$ Each task force was composed of five to seven members from various oil and gas companies. Many of the industry representatives with whom she had consulted in the fall of 1983 comprised the study group membership. It is notable that the chairmen of each group had been in contact with her, in an advisory or consultative capacity, before they were recruited to be in the study groups. ${ }^{13}$ Therefore, it is not surprising that many of the general objectives that developed between November 1983 and January 1984 were found in various forms in each study group's recommendations. The groups were given terms of reference, or questions that Carney wanted answered, and were then told to submit a report to her by 15 March 1984 . There were between seven and ten questions in the terms of reference; they were specific to the particular program or policy that the study group was being asked to examine." For example, the "Price/ Taxation/Revenue Sharing" study groups were asked, 
among other things, to suggest changes to the pricing system for oil and natural gas, recommend when the changes should be made, assess what affect the pricing changes would have on consumers, and discuss how the recommendations would impact on the revenue shares of the federal and provincial governments."s Needless to say, each study group provided detailed reports.

On 24 and 25 March 1984 each study group met with Carney and various other Conservative MPs and advisors who were putting together an overall PC economic policy. The meetings were designed to discuss each group's recommendations and provide an opportunity for the party's policy makers to clarify issues and ask more questions. ${ }^{46}$ Although Camey stated in a private meeting with the shadow Priorities and Planning Committee, in January 1984, that "[the task forces'] recommendations will be for government policy not the election," 47 many of the study group's recommendations did in fact permeate the PC election platform that was revealed in Prince Albert, Saskatchewan in July of 1984 . Seven of the twelve specific policies outlined in the Prince Albert statement were recommendations of the study groups. ${ }^{49}$ The remaining policies were either political statements, or were beyond the scope of the study groups' terms of reference.

Carney developed and pursued some policies herself, without going through a study group. One was the development of the Atlantic offshore resources. A month before the Prince Albert statement, while the Conservatives were still in opposition, they announced an agreement in principle with Newfoundland regarding the ownership and development of offshore resources. ${ }^{99}$ This was an unusual and significant accomplishment. Throughout the 1970 s and early 1980s Newfoundland and Ottawa had been fighting a bitter war over the jurisdiction of offshore resources. Newfoundland claimed that the resources of the continental shelf belonged to the province, and that the principle of 
ownership should be enshrined in the constitution as it is for land-based provinces. After several years of failed attempts to reach an agreement, Newfoundland took the case to the Supreme Court which ruled in favour of the federal government.so Camey remembers solving the issue by going to Newfoundland and offering: "Why don't we just leave the issue of jurisdiction. Why don't we just treat it 'as if' you owned [the resource]." The Newfoundland minister of energy, William Marshall replied, dumbfounded, "You mean, like Alberta?" Carney said, "Yeah, like Alberta. Why don't we nun the Offshore 'as if' you owned it like Alberta."st Therefore, on the basis of this rationale, the Conservatives formulated the agreement using all the principles relevant to land-based oil and gas resources and applied them to the offshore. Both sides were satisfied, not only with the content of the agreement, but also with the fact that they had achieved something in ten months that the Liberals had been unable to accomplish in ten years.

The agreement was a significant accomplishment for the Conservatives and for Carney. Immediately following its signing, she received congratulatory letters from Marshall, Newfoundland PC MP John Crosbie, and Mulroney. The following excerpt from Crosbie's letter provides an insight into Camey's role in the negotiating and policy-making process: "You certainly kept the negotiations moving along and kept all interested parties involved so that the outcome is one widely supported, not only in Newfoundland but across the country." Mulroney's comments were more brief but in the same tone. He congratulated her on the accomplishment of the agreement and said that its success "was also a tribute to your talents for conciliation, tough negotiation, and straight talk."s The achievement of reaching an agreement with Newfoundland while the PCs were still in opposition can be attributed in large part to Camey. Her own fundamental belief that "the resources belonged to the provinces ..." "s 
was at the centre of her approach toward energy policy. Critics shrugged off the Conservative initiatives, stating that it is much easier to talk and make policy when in opposition than implementing it when in power.ss

When the PCs were elected in the fall of 1984 Mulroney, not surprisingly, appointed Carney as the first female minister of EMR. Even though she had gone to great lengths to develop a Conservative energy policy while in opposition, there was another reason behind her appointment to the energy portfolio. As an MP for Vancouver she was from the West, but not from Albertathe Eastern provinces would have seen an Alberta MP as being biassed towards Alberta's energy concerns. Therefore, Carney satisfied, to a degree, the Western and Eastern interests. Within her first week of holding the portfolio she met with the energy ministers of Alberta, Saskatchewan, and British Columbia.s This was a change from the previous Liberal governments. There arose a spirit of cooperation and a hope that a lasting energy agreement could be negotiated between the federal government and the producing provinces.

However, before the process could begin, Carney wanted to put her stamp on EMR. Her first move was controversial-she hired Harry Near as her chief of staff. In 1979 Near had been the executive assistant for Ray Hnatyshyn, PC energy minister in Clark's government; after the PCs lost the 1980 election Near established a consultancy firm, Public Affairs International." Criticism erupted when Carney confirmed that Near would be paid $\$ 50,000$ for a five-month contract. ${ }^{s 8}$ She justified her decision with the argument that Near "was invaluable because of his awareness of all the pitfalls facing a new administration." $\$$ Carney had been in contact with Near during her time as opposition energy critic and she knew about his grasp of the industry's expectations and that he had experience in government administration. The new 
government needed as many knowledgeable personnel as possible to assist in its operations and it was imperative that that personnel support the ideological objectives behind PC policies.

Ignoring the prime minister's objections, Carney also decided to retain Paul Tellier as deputy..$^{\circ 0}$ Mulroney was suspicious of Tellier, as were Alberta's officials, because Tellier was linked to the Liberals and the NEP. Carney argued that Tellier was essential because of this background. If the Conservatives were going to dismantle the NEP, it would be advantageous to have someone who knew what it was all about and who could assist in taking it apart. Her argument was persuasive and Tellier remained deputy minister.

The officials within EMR were thus initially caught offguard by Carney. Normally, when there is a change in government, it is the responsibility of the bureaucrats to brief the new minister about what the department has been doing. The senior officials in EMR provided the minister with a transition book outlining "what they thought the issues were and how they [the issues] should be approached."61 Carney rejected the advice of her senior bureaucrats then briefed them on the issues and explained the direction that policy would follow under the PC government. The EMR officials were stupefied and dismayed. They had known about the Conservative position before and during the election, but they did not anticipate that Camey would have a firm energy policy developed upon assuming office. If the policy had already been developed without the participation of department officials, how would they be able to negotiate and implement the policies effectively? The differences between Camey and the senior EMR officials would cause some tension and difficulty in the operation and functioning of the department and will be discussed in the context of the 
negotiations that took place between the federal government and Alberta.

Most of the policy platform of the PCs in opposition became government policy once they assumed power. On 13 December 1984, Carney presented a document to the cabinet Priorities and Planning committee entitled "Energy Discussions: An Overview." There were two sections of particular importance: a section entitled "Energy Platform" and another called "Fundamental Changes to Energy Policy." The "Energy Platform" section contained five goals which were identical to the five goals set out in the introduction of the Prince Albert statement. The five goals were: energy as an engine of growth and job creation, self sufficiency and energy security, enhanced Canadian participation, fair treatment for consumers and producers, and cooperation between federal and provincial governments and industry. In addition, five of the six Fundamental Changes to Energy Policy were contained in the Prince Albert statement."

Since the study groups' recommendations comprised most of the Prince Albert statement's policies, and those policies were then reflected in the "Fundamental Changes to Energy Policy," the recommendations became a significant part of the Conservative energy policy when they took power. The first agreement, signed in February 1985, was the Atlantic Accord. Its basic principles were the same as those outlined in the early June 1984 agreement in principle. ${ }^{6-1}$

Negotiations with the Western provinces were a little more difficult and deadlines for an agreement had to be extended twice. Once the PCs took power and opened the finance books, they found the deficit was in worse shape than they had anticipated and Michael Wilson, the new minister of finance, put considerable pressure on Carney to keep some of the taxes that were found in the NEP. ${ }^{\circ 5}$ However, she was bound by the promises made in the 
Prince Albert statement, that the PCs would essentially remove or revise all forms of taxation in the NEP.

Another important reason for the Carney's difficulties in negotiating with Alberta was the existence of an unflattering memorandum based upon a leaked federal document that was circulated among Alberta officials. In this memorandum, dated 26 October 1984, a provincial bureaucrat summarized "observations received from a senior federal bureaucrat concerning the status of federal/ provincial negotiations." ${ }^{66}$ It depicted Carney as an overwrought and uninformed minister. She was described as having no credible staff, and of being disorganized, mercurial, and lacking personal credibility "especially when she is under any amount of pressure." ${ }^{\circ}$ The document also stated that "Federal Finance will have major input into energy policy during the first term of the Mulroney government." ${ }^{68}$ It seems apparent that this back room manoeuvre was intended to undermine the PC policies by attempting to sabotage the negotiations and to shift the confidence of the Alberta officials away from Carney and EMR to Michael Wilson and the Finance Department. If Alberta officials believed that EMR was disorganized under Carney, and that the real control over energy policy was in the hands of the Finance Department, they would be more likely to work with the finance officials. Many of the finance officials were the ones who had created the NEP. Thus, by shifting the focus away from the EMR officials to the finance officials there would be more opportunity for the bureaucracy to maintain aspects of the NEP that they expected would be discarded by Carney. It is ironic that provincial officials apparently believed the negative comments conveyed by the same federal bureaucrats who were so hated by the province. The comments adversely affected future discussions. Before 26 October 1984 Alberta officials had been rather indifferent towards Carney and EMR; after the memo was circulated to the provincial 
officials, the tone of the internal provincial memoranda became decidedly more disparaging towards Carney and EMR.

An excellent example of the changed attitude is in a 30 November 1984 memorandum from G.B. Mellon, the Alberta deputy minster of energy, in which he made observations and comments based upon industry and government sources. His remarks were sharp: "Federal EMR is in a state of suspended animation, with little or no meaningful communication between Ms. Carney and her senior officials." The memorandum went on to represent the officials in the federal Finance Department as "being in full control of [the department's] mandate [and] . . . very clearly have the final say (at the bureaucratic level) on fiscal matters." The document did not mince words in its final assessment: "[Carney] appears to be inadequately or poorly briefed, with no obvious game plan or strategy to follow up on the government's pre-election commitments. Mr. Wilson, in contrast, is well briefed by his officials and, moreover, seems to have the authority to hold back or veto any decisions or proposals put forward by EMR." ${ }^{\circ}$ However, the bottom line is that despite the severely critical remarks made about Carney and how she administered EMR, the claims that there was no strategy and no game plan in EMR are patently false, ${ }^{\text {, }}$ particularly since there is considerable evidence that the comprehensive study undertaken by Carney as opposition energy critic was translated into the government's energy policy.

Indeed, almost all of the provisions in the Western Accord, eventually signed on 28 March 1985, are found, in some form, in the study group recommendations." Certainly, there were changes made in the negotiated agreements concerning the details of how oil and gas prices were to be deregulated, how taxes were to be phased out, and to what extent revenues were to be shared. But the basic premises from which the details were negotiated came 
mostly from the study group recommendations. The Western Accord phased out the PGRT that was used to pay for PIP grants and removed all other NEP taxes in the oil and gas fields. Incentives would no longer be in the form of grants, but would be tax-based. The federal government agreed to tax profits only and not revenue, and not to impose export levies on oil and gas. It also stipulated that it would monitor the oil industry to ensure that it would reinvest the money that the government was not taking in taxes. All Canadian oil would be purchased at world prices, which were dropping significantly anyway, and finally, there would be a force majeure clause in case of an emergency to protect Canadian interests from sudden fluctuations in oil prices. ${ }^{n}$

Not all of the study group recommendations were included in the final policy. For example, the Independent Petroleum Association of Canada (IPAC) study group suggested that the two-tiered pricing level be maintained and proposed a simplified royalty and taxation system that included a resource levy and resource tax as a means for the federal government to reap revenues from a nonincome tax stream. Capital expenditure grants were also rejected because Camey wanted to rely solely upon taxbased incentives that would be non-discriminatory. There would be no special subsidies to Canadian companies. ${ }^{3}$ Nevertheless, Alberta and the industry were relatively satisfied. Premier Peter Lougheed of Alberta told a media gathering after the announcement of the Western Accord that he was pleased with the agreement and the manner in which negotiations were conducted by the Mulroney government. ${ }^{\text {"4 }}$

On 30 October 1985 a statement on frontier energy policy was released. Every point could be found in the Prince Albert statement and the study groups' recommendations. Briefly, the federal government would not discriminate against foreign investment in the Canadian 
oil and gas industry. The contentious 25 per cent "backin" the contentious provision that gave the Crown an automatic interest in every development, past or future, on Canada Lands, was abolished but a minimum of 50 per cent Canadian ownership of producing wells on Canada Lands was maintained. PIP grants were phased out but an exploration tax credit took PIP's place in order to encourage exploration on the frontier lands."

Policies that were recommended by the study groups were: elimination of the Crown share; non-retroactive and non-confiscatory 50 per cent Canadian Ownership Requirement-private sector solutions for ownership; rights issuance based on single, quantifiable criterion; repealing or limiting of extraordinary powers of COGLA; profit sensitive royalties; 25 per cent investment royalty credit; and 25 per cent refundable (at 40 per cent), exploration tax credit above $\$ 5$ million per exploration well. Not included in the policy from the recommendations were: Canada Benefits, a 50 per cent Canadian Ownership Requirement for exploration permits as well as for production licenses, and an earned depletion allowance to encourage exploration on Canada Lands in lieu of PIP grants. $^{76}$

The Agreement on Natural Gas Markets and Prices, signed on 31 October 1985 took a little longer to negotiate, but it represented a major accomplishment in federalprovincial relations. The previous federal government had not been able to come to a satisfactory agreement with Alberta, British Columbia and Saskatchewan regarding natural gas markets and pricing. Once again, many of the provisions within the agreement could be found in various forms within the study groups' recommendations and the Prince Albert statement. The agreement created a more "flexible and market-oriented pricing regime ... for the domestic pricing of natural gas," provided for buyers and sellers to negotiate freely the interprovincial trade of natural 
gas, provided for the review of the National Energy Board's policy of a 25 year surplus of natural gas before it could be exported, and stipulated that exported natural gas would not be sold at a cheaper rate than the price Canadians paid. ${ }^{n}$

Once again the producing provinces as well as the industry were satisfied with the agreement with Ottawa. Alberta Energy Minister John Zaozimy was quoted as saying that the Natural Gas Agreement was "one that we in Alberta can feel very comfortable with." As for the consuming provinces, Ontario Energy Minister Vince Kerrio and Deputy Minister Duncan Allen, "reacted favourably after an initial reading of the new federal policy" However, the next day Ontario Premier David Petersen stated, "I'm not satisfied-there are improvements I believe we could have had."so Bruce Wilson of the Consumer Association of Canada also expressed dissatisfaction because he had been expecting more significant price reductions of natural gas than appeared to be forthcoming from the agreement."s! Ontario's reaction should not be surprising. Since the government was headed by the provincial Liberal party, unless there was a noticeable drop in natural gas prices for Ontario consumers, it would be politically dangerous for the Ontario Liberal government to be completely supportive of the federal PC government's initiative.

Although the Ontario government complained that it had been left out of the negotiations, it is important to note that both Alberta and Ottawa had been meeting and corresponding with Ontario and Quebec throughout the negotiations."2 In an Alberta memorandum dated 5 December 1984, regarding a meeting between Alberta and Ontario energy officials, it was Alberta's understanding that Ontario would accept crude oil deregulation if it could be assured that natural gas would not be sold to Americans at a cheaper rate than that paid by Canadians." The main concern for Ontario was that its industry remain 
competitive with the American competition; the provisions in the Natural Gas Agreement certainly allowed for market forces to prevail while meeting Ontario's concerns.

Within one year of becoming minister of EMr, Carney had successfully dismantled the NEP and reached amicable agreements with all of the producing provinces. However, NEW DEMOCRaTIC PARTY energy critic Ian Waddell called Carney's policies "disastrous" and said that "Camey bought the myth of the oil industry." From a socialist point of view, the policies would seem to be deleterious since they sought to reduce the government's role in the oil and gas industry. For those who believed that market forces should prevail and there should be as little government intervention as possible, the policies were reasonable. Carney, who had faith in market forces and her own abilities, defended her energy policy: "They were carefully designed policies. I did my homework. I knew what I was going to do. I went out and talked to everybody. I had task forces. I figured it out in my own mind and I'd got through caucus what we were going to do."'ss There is little doubt that her success would not have been possible without the work that was accomplished while she was opposition energy critic, particularly since after the 1984 election there were a great many more PCs from the consuming provinces. It would have been more difficult to develop policies so favourable to the producing provinces in an environment where Western Canadians comprised less than 25 per cent of elected PCS, whereas in opposition they had constituted over half of the PC seats. In addition, Carney would have had to rely more on the bureaucracy for advice, something which she did not have to do in opposition.

But what exactly influenced the policy that emerged? It is difficult to ascertain just how much of the Conservative energy policy was ideological or how much was influenced by the industry. The ideas that Carney had regarding the nature and purpose of the oil and gas industry were very 
similar to the way the industry perceived itself. Yet, in direct opposition to the Liberal party idea of a strong central government, she advocated a different federalprovincial relationship that gave the provinces more autonomy. Carney believed:

fundamentally, that the resources belonged to the provinces ... that's a different view than the NEP concept that you [sic] shared. Ontario didn't share gold . . . the resources belonged to Alberta and B.C. and Saskatchewan, therefore that was the founding principle. . . . [T]o me the provinces owned the resources. Therefore the object was to get the Feds out. ${ }^{* 6}$

The hated symbol of Liberal economic control and centralization was the NEP and if the Conservative vision of the new Canada was to be put in place the NEP had to be eliminated. The Conservative party itself, subscribed to the ideology that market forces should be left to guide the economy, therefore less government would allow business to operate efficiently and profitably. That being said, Carney stated that she looked to the industry for advice and recommendations because they knew what their problems were." However, once she became the minister of EMR, she also had to represent the consumers of Ontario and Quebec when negotiating the agreements. Nevertheless, it is sometimes quite difficult to distinguish whether the policy was a direct result of ideology or industry influence." Where does one draw the line? In this case, it is even more difficult because Carney, the PCS, and the industry shared a similar ideology.

The PCs, under Mulroney, formulated the energy policy that dismantled the NEP while they were in opposition. Carney, who coordinated the energy policy-making effort, had several meetings with the provinces and various 
members of the study groups during her tenure as energy critic between September 1983 and July 1984. From these meetings and the study group reports, she and her staff sifted through the information, developed the PC energy policy in opposition, and directed that policy through caucus. Regarding her role in the energy policy formulation Carney stated, "I did all the work as an MP and critic. All the preliminary [work], all the policy formulation was done before we were in government. ... We had developed our task forces, we did develop our platform, we did develop everything [in opposition] and we hit the ground running." The substance of the policy was based both on ideological considerations and industry and provincial influence. In fact, the two were indistinguishable. Once they attained power in 1984, the Conservatives could put their policies into practice. They did that with the Atlantic Accord, the Western Accord, the Agreement on Natural Gas Markets and Prices, and the frontier energy policy. The process represented a significant shift not just in policy-making but in how the country as a whole was to function. It also demonstrated the importance of Carney as the person responsible for directing and devising the program that dismantled the NEP. In doing so she achieved her own personal goals-improved government-industry relations and more cooperative federal-provincial relations.

Although Carney's approach to creating the PC energy policy was not necessarily unique in the context of Tory policy-making in general, she was one of the few cabinet ministers who actually translated the opposition platform into government policy when the party assumed power. Mulroney's PCs were very well organized; each critic had been given a specific outline of how they should gather information and when the policies were to be presented to the caucus for approval. The approved policy was then to be implemented to the greatest possible extent when the PCs took control of the government. The most notable 
failure in this process was Michael Wilson who, as minister of finance, was unable to translate his deficit reduction program into action. Moreover, when his 1985 budget increased the federal sales tax and provided more corporate tax breaks and tried to de-index Old Age Security and Family Allowance payments, Mulroney backed off. Social programs were, in his words a "sacred trust." Carney succeeded where other ministers failed because she was determined to push her policies through and was uncompromising with the bureaucracy, the provinces, and the PC caucus once she became minister of EMR. She also believed fundamentally in almost all of the industry recommendations and therefore it was much easier for her to be firm on those matters. The final contents of the agreements, inasmuch as they reflected the policies created in opposition, were a direct result of Carney's intimidating, inflexible, and tough attitude.

The process of policy development revealed both strengths and weaknesses. By developing the essential tenets of the policy while in opposition, Carney avoided relying too heavily upon the bureaucracy for ideas. The process also emphasized the conciliatory role that the PCs desired when dealing with the provinces and industry in their quest for Canadian unity and economic growth. However, the potential problem with this approach in the energy sector was that only industry and the producing provinces would provide input, while the consumer and national interests would become secondary. Carney attempted to address the problem during the negotiations once she became minister, but it would appear from the agreements that the industry view prevailed. Nevertheless, she argued that less government intervention in the affairs of the oil and gas industry would mean a stronger economy for Canada and create jobs across the country; therefore, her policy would succeed for all interested parties. 
There is the possibility that Carney might have failed in her role if oil prices had increased dramatically rather than decline as they did. There would have been a significant amount of pressure from the consuming provinces to maintain strong controls over oil and gas prices and the exploration and development of Canadian oil and gas. However, Carney was committed to the deregulation of oil and gas pricing and other aspects of the industry. It is unlikely that she would have advocated permanent government intervention but rather would have implemented some type of temporary measure that would satisfy both producers and consumers, as was outlined in the force majeure clause of the Western Accord. Healing the rifts between the Western provinces and the federal government and between the oil and gas industry and Ottawa, was a high priority for both Carney and the Mulroney government, therefore, some compromises would have been necessary in order to mollify all the parties. The collapse of world oil prices in 1986 only temporarily tempered the success of Carney's energy policy; the ultimate test was in the long-term ability of the government's policy to adapt to fluctuating economic conditions. In the end, it has survived."

\section{NOTES}

- It was with great difficulty that I managed to gain access to the federal documents necessary to research this paper. A special thank you goes out to Senator Patricia Carney and her executive assistant Janice Whitters who both provided assistance in my research. More difficulty ensued when I tried to gain access to provincial government information but I was eventually allowed to view small amounts of these documents. The Alberta Freedom of Information and Protection of Privacy Act normally requires substantial fees to be paid in order to view documents. Without the assistance of Irene Jendzjowsky, an archivist at the Provincial Archives of Alberta, I would not have been able to view any of the information.

'The Globe and Mail, 5 September 1984. 
'Stephen Clarkson, Canada and the Reagan Challenge (Toronto: James Lorimer \& Co., 1985), 71-81.

'Bruce Doern and Glen Toner, The Politics of Energy: The Development and Implementation of the NEP (Toronto: Methuen, 1985), 2.

4For an in depth examination of Canadian energy policy please refer to: Doern and Toner, Politics of Energy; John N. McDougall, Fuels and the National Policy (Toronto: Butterworth and Company, 1982); and John Richards and Larry Pratt, Prairie Capitalism: Power and Influence in the New West (Toronto: McClelland and Stewart, 1979).

${ }^{5}$ Kenneth Norric and Doug Owram, A History of the Canadian Economy 2nd Edition (Toronto: Harcourt Brace, 1996), 444-47. The authors made an excellent point regarding the issues of regional fairness and economic management: "The concern with economic management stemmed from the recognition that provinces had considerable economic powers under the Constitution, and that they would be led to use them in ways that were consistent with their own economic objectives, even if these conflicted with central government objectives. . . . Notions that the federation operated consistently to the advantage of some regions to the disadvantage of others were rife in the 1970s.... Ontario's interests had always been equated, fairly or not, with those of the national government. Energy issues, in particular, altered this perception somewhat, as the province began to press more openly for policies that reflected its status as the major consuming province." See also, Doern and Toner, Politics of Energy, 89-92, 180-85.

${ }^{6}$ The Honourable Ray Hnatyshyn, the minister of EMR for the Clark government, hailed from Saskatchewan.

${ }^{7}$ For a discussion of the brief Clark government see, Jeffrey Simpson, Discipline of Power: The Conservative Interlude and the Liberal Restoration (Toronto: MacMillan of Canada, 1980). See also Doern and Toner, Politics of Energy, 190-191 for a concise assessment of the difficulties Clark's government had negotiating with Alberta. ${ }^{8}$ Doern and Toner, Politics of Energy, 93, 102; A.M. El Mokadem and others, OPEC and The World Market 1973-1983 (London: Eastlords Publishing, 1984), 32-35; Peter Foster, Blue-Eyed Sheiks: The Canadian Oil Establishment (Toronto: Collins, 1979), 312. 9 John F. Helliwell, "Canadian Energy Policy," in After the Second Oil Crisis, ed. Wilfrid L. Kohl (Lexington, Massachusetts: D.C. Heath and Company, 1982) 232-33. The world price in 1980 was around $\$ 40$ per barrel in Canadian funds or $\$ 35$ per barrel in 
American funds. All dollar values are Canadian unless otherwise noted.

${ }^{10}$ Stephen Clarkson and Christina McCall, Trudeau and Our Times Volume 2: The Heroic Delusion (Toronto: McClelland \& Stewart, 1994), 170-75.

"Doern and Toner, Politics of Energy, 41-45; Peter Foster, The Soncerer s Apprentices: Canada's Superbureaucrats and The Energy Mess (Toronto: Collins, 1982), 142-47.

12 In 1980, the price of oil from a Canadian well, excluding transportation costs, was $\$ 16.75$ per barrel; the delivered price to central Canada was $\$ 18$ per barrel; and the landed cost of imported oil to Canada was $\$ 38$ per barrel. The federal subsidy amounted to $\$ 20$ per barrel or approximately 53 per cent of the cost. Previously, the OICP was paid out of general revenues. Price Waterhouse, The National Energy Program Second Edition (Privately Printed, 1982), 17-18. See also, Doern and Toner, Politics of Energy, 330.

"Natural gas liquids are defined as propane, butane, and ethane. "Department of Energy, Mines and Resources, hereafter EMR, The National Energy Program, 1980 (Ottawa: Supply and Services Canada, 1980), 14-15. See also, idem, The National Energy Program: Update (Ottawa: Supply and Services Canada, 1980), 73.

"Doern and Toner, Politics of Energy, 330.

${ }^{16}$ Ibid., 391. The funds from the COA were used to help pay for Petro-Canada's purchase of Petrofina. In addition, money from the COA was earmarked to finance the Trudeau government's loan package of $\$ 500$ million to Dome Petroleum if it became necessary. ${ }^{17}$ Canada Lands include the Yukon and Northwest Territories as well as the Arctic, Pacific and Atlantic offshore areas.

${ }^{18}$ EMR, NEP 1980, 2, 45-47, 113.

${ }^{19}$ Bruce G. Pollard, "Canadian Energy Policy in 1985: Towards a Renewed Federalism?," Publius 35 (Spring 1991): 166. See also Kenneth Norrie, "Energy, Canadian Federalism, and the West," Publius 14 (Winter 1984): 88.

${ }^{20}$ Doern and Toner, Politics of Energy, 206.

"Norrie, "Energy, Canadian Federalism, and the West," 88-89.

2 David Bercuson, J.L. Granatstein, W.R. Young, Sacred Trust? Brian Mulroney and the Conservative Party in Power (Toronto: Doubleday Canada, 1986), 13, 18.

${ }^{23}$ Toronto Sun, 11 September 1983.

${ }^{24}$ Bercuson, Granatstein, Young, Sacred Trust?, 13.

2s Vancouver Province, 18 September 1984. 
${ }^{26}$ See in particular The Financial Post, 21 March 1970, p.5 for her article describing the delays experienced by PanArctic in their exploration of the Arctic for oil and gas. See also her articles in Maclean 's, November 1969, 11, 17-21; May 1970, 1-3, 6; May 1971, 46-47, 49-50. For a glimpse of her business writing in general see Vancouver Sun, 14 November 1968; 18 November 1968; 2 December 1968; 4 December 1968; 6 December 1968; 9 December 1968; 11 December 1968; 13 December 1968; and The Financial Post, 28 March 1970, 29.

${ }^{27}$ Vancouver Sun, 8 November 1968.

${ }^{28}$ Doem and Toner, Politics of Energy, 100.

${ }^{29}$ Vancouver Province, 18 September 1984; Vancouver Sun, 22 March 1984. The following is a list of the personnel who worked on the report and their credentials: Project Director - Pat Carney, B.A.; Project Economist - Frank C. Basham, B.A., M.A.; Senior Economists - Dominique F. Prinet, B.A.Sc., MBA, Terence D. Smyth, B.A.Sc., M.S., Peng; Social Anthropologist - H. Philip Thomas, A.D., M.A.; Senior Researcher - George Braden, B.A.; Research Assistants - Joan V. Hornal, B.Sc, Dominique M. Prinet, B.A., Neil Pascal, Francis Blackduck; Copy Editor - D.D. Thomas Carney, B.A.; Production Coordinator - Brenda J. Basham., in Gemini North, Social and Economic Impact of Proposed Arctic Gas Pipeline in Northern Canada Book 4 (Vancouver: Privately Printed, May 1974), 106. However, a controversy surrounds the credentials of the people employed by Carney's company and the quality of Gemini North's reports. In a book by Robert Page entitled Northern Development: The Canadian Dilemma (Toronto: McClelland \& Stewart, 1985), 224, Page erroneously referred to Gemini North as a "group of consultants, made up of journalists." In reality, the only journalist was Carney and she was not working as a journalist then. Page also stated that Carney's company "tried to provide the socio-economic data to flesh out the Arctic Gas application ... [and] proved to be a major embarrassment to their clients ... [with their] simplistic assumptions on the cash value of native country food and other analysis. . . . Arctic Gas, embarrassed by these superficial efforts, quietly dropped the Gemini North evidence before they presented their case to the NEB [National Energy Board]. Like many corporations in the early 1970 s, Arctic Gas had only limited in-house expertise and it was burned by entrepreneurs passing themselves off as experts." From Carney's perspective, the depiction of her company's work by Page is inaccurate. She saw Gemini North's research as ground-breaking work that presented life in the northern settlements in a very realistic and graphic 
manner. It was not acceptable at the time to recognize or address the northern living conditions that Gemini North reported in its studies. In a recent interview, Carney explained: "Some of the things that we discovered are now part of the conventional wisdom, the fact that the infant mortality rate was $x$-times the rate of the south; the fact that alcoholism and crimes and alcohol abuse were $y$-times the rate of the south, [these facts] had never been actually formulated before our report. ... So when it [the report] came out, people said 'Oh, you can't say that! You can't say that about Natives! You can't say that [the people in] Arctic- Red River drink hair sprayl' But they did." Senator Patricia Camey of British Columbia, interview by author, 26 November 1996, Ottawa, tape recording and transcript, 5-6.

During the time that Gemini North conducted its studies of the Upper, Lower and Central Mackenzie region there was little quantitative data concerning the socio-economic impact of oil and gas development in the area. Thus the information Gemini North collected was considered to be base data. Many other sources of the time state that "not all the data that is required for regional planning will be available from existing stocks of information." K.S. Wood, Towands A Social Accounting System for Regional Planning in Canada s N.W.T. (University of Western Ontario, September 1969), 101. See also, for an annotated bibliographical entry of some of Gemini North's reports for Canadian Arctic Gas Pipeline, Lynda Howard, Issues of Public Interest Regarding Northerm Development: An Annotated Bibliography (Calgary: Pallister Resource Management, 1984), 218.

${ }^{30}$ Kathryn O'Handley, Canadian Parliamentary Guide (Toronto: Gale Canada, 1995), 295-96.

"Maclean', 30 April 1979; Ottawa Citizen, 4 April 1985; Toronto Star, 7 November 1986.

"Glen Toner, "Stardust: The Tory Energy Program" in How Ottawa Spends 1986-1987: Tracking the Tories, ed. Michael J. Prince (Toronto: Methuen, 1986), 123.

${ }^{33}$ National Archives of Canada (NAC), MG 32 B43, Honourable Patricia (Pat) Carney Papers, Vol. 2 File 2, Energy Policy - Appraisal and Priorities 1983 - 1984 File 1, "Steps in the Policy Process."

"Pat Carney Papers, Vol. 5 File 13, Progressive Conservative Party - Energy Policy 1984 File 2, F.H. Deacon Hodgson Inc., Political Alerts, "The Conservatives Running Ahead," 13-18.

${ }^{35}$ Pat Carney Papers, Vol. 5 File 11, Progressive Conservative Party

- Energy Policy n.d., 1983, Memorandum, "Energy Policy," 10 November 1983, 1. 
${ }^{36}$ Pat Carney Papers, Vol. 2 File 3, Energy Policy - Appraisal and Priorities 1983-1984 File 2, "CANEP - The Canadian Energy Plan: Creating National Wealth Third Draft," 30 November 1983, 1-2. ${ }^{37}$ Ibid.

${ }^{38}$ Pat Carney Papers, Vol 1 File 6, CoGLA - correspondence, clippings, speeches 1983-1984, Forwarded Letter of Esso Resources Employee from Harvie Andre to Pat Carney, 31 October 1983; Vol. 1 File 12, Canadian Hunter Exploration - speech, submission, J.K. Gray to Pat Carney "Moving to a New Opportunity - Speech to Canadian Association of Petroleum Landmen," 15 September 1983; J.K. Gray to Pat Carney "REP: A Realistic Energy Policy - prepared for the Royal Commission on the Economic Union and Development Prospects for Canada," 10 November 1983; J.K. Gray to Pat Carney "Energy Policy Discussions," 12 December 1983; Vol. 2 File 1, Energy - Progressive Conservative Party Caucus briefings 1983, Interview Records (I.R.), "Meeting with the Canadian Association of Oilwell Drilling Contractors," n.d.; "Harvie Andre," 12 September 1983; "Private Dinner at the Ranchmen's Club Calgary," n.d.; "TransCanada Pipelines (TCPL) Dinner in Toronto," 4 October 1983; "EMR Briefings - General Overview," 13 September 1983; Vol. 2 File 2, I.R., "Oil and Gas Briefings - John Beddome and Terry Hargreaves of Dome Petroleum," 19 September 1983; "Oil and Gas Briefings - Bill Stuart of TCPL," 19 September 1983; "John Zaozirny [Alberta Energy Minister]," 21 September 1983; "Briefing Notes: Saskatchewan," n.d.; "Briefing Notes: Ontario," n.d.; Vol. 3 File 15, National Energy Program 1983, Jock Osler to Pat Carney "Notes for Pat Carney MP," 12 October 1983; Vol. 4 File 1, Natural Gas - General, Charles McMillan to Pat Carney "Attached Paper - Energy Policy: An Imperial Oil Perspective, A New Look at a New Time," 7 December 1983; Vol. 5 File 5, Petrochemical Industries - General - 1983-1984, Forwarded Letter, Prairie Pacific Energy Corp. to Brian Mulroney, "Re: Petro-Canada," 6 October 1983; Vol. 6 File 13, Westcoast Transmission Company Limited - correspondence concerning Canadian gas imports 1983, A.H. Willms to Pat Carney, "Status of U.S. Legislative and Regulatory Proceedings Relating to Canadian Gas Imports," 29 September 1983.

${ }^{39}$ Pat Camey Papers, Vol. 2 File 3, Energy Policy - Appraisal and Priorities 1983-1984 File 2, "Federal Energy Policy: A Discussion Paper," December 1983, 3. 
${ }^{40}$ Pat Camey Papers, Vl. 2 File 1, Energy - Progressive Conservative Party Caucus briefings 1983, I.R., "Private Dinner at the Ranchmen's Club - Calgary", n.d.

"Pat Carney Papers, Vol. 2 File 6, Energy Policy - draft 1983, "Draft Energy Policy for The Progressive Conservative party," n.d., 86-99. "2 Pat Carney Papers, Vol. 2 File 3, Energy Policy - Appraisal and Priorities 1983-1984 File 2, Draft Letter Pat Carney to study group members, n.d.; Vol. 1 File 25, Energy - briefing book on oil and gas programs [Mar.] 1984 File 2, Canadian Petroleum Association (CPA) Task Force Report "Price and Revenue Sharing," makes reference on the first page to the letter sent to them on 18 January 1984.

"3 Pat Carney Papers, Vol. 2 File 6, Energy Policy - draft 1983, "Draft Energy Policy for the Progressive Conservative Party," n.d. 83-85. Ted Best (vp Ops, ap Resources Canada Ltd.), chairman of the CPA study group on revenue sharing; Bernard Isautier (Pres. \& CEO, Canterra Energy Ltd.), chairman of the Independent Petroleum Association of Canada (IPAC) study group on revenue sharing; Bob Blair (Pres. \& cro, Nova Corporation), chairman of the oil sands and heavy oil development study group; Vern Horte (Board Chairman, Progas Ltd.), chairman of the study group on natural gas export pricing policy; Arnie Nielson (Board Chairman, Canadian Superior Oil Company), chairman of the Canadian Oil and Gas Lands Administration (COGLA) study group; Gerry Maier (Pres. \& ceo, Bow Valley Industries Ltd.), chairman of Petroleum Incentive Program (PIP) study group.

"Ibid., 86-99.

is Ibid., 83-85, 88, 91. The collective members of the CPA and IPAC study groups were Bernard Isautier, Don Barkwell (Exec. VP, Norcen Energy Resources Ltd.), Dick Haskayne (Pres. Home Oil Company Ltd.), Gerry Henderson (Pres. Chevron Canada), Gerry Maier, Ted Best (Chairman CPA), and Joe Dundas (Pres. IPAC). The first five were also on the PIP task force. The CPA and IPAC were associations composed of oil and gas companies. The cPa represented the interests of the foreign-owned majors like Imperial Oil, Shell, Texaco and others, whereas IPAC represented most of the 'Canadian junior' companies as well as the "Canadian majors and the second-line Canadian companies [Pan Canadian, Norcen, Home Oil, Canterra, Husky, Bow Valley Industries, and others] ... with the exception of Petro-Canada, which withdrew in 1981." Doern and Toner, Politics of Energy, 205-07, 237, 245. 
${ }^{26}$ Pat Carney Papers, Vol. 1 File 25, Energy - briefing book on oil and gas programs [Mar.] 1984 File 2, I.R. of Pat Carney and caucus representatives with each study group.

${ }^{47}$ Pat Carney Papers, Vol. 2 File 2, Energy Policy - Appraisal and Priorities 1983-1984 File 1, Minutes of the Economic Development Envelope Committee, 23 January 1984, 1.

${ }^{48}$ Natural Resources Canada (NRC), Document EP 5000-2-2, Memorandum, "Prince Albert Caucus, Progressive Conservative Agenda for Government, Policy Area: Energy," 5 July 1984. The twelve specific policies needed to achieve the five goals were as follows: i) the removal of the nine per cent sales tax on gasoline for all primary industries; $i$ ) the taxation of a company's profits instead of taxing its gross revenue and reduction of front-end taxes on large projects; iii) the assurance that a PC government would protect consumers from any sudden price changes; iv) the adoption of market- sensitive pricing for natural gas exports with the provision that Canadian consumers would pay less than American consumers for Canadian gas; v) the combination of industrial conservation programmes into one fund to ensure that "the most cost effective projects" would proceed; vi) the acceleration of the development of the oil sands projects; vii) federal government assistance under the PCs for assist provincial initiatives "to find new and large markets in the United States" for a number of alternative energy sources like hydro-electricity, tidal and nuclear power, viii) the assurance that "faimess, equity and opportunity" would direct the federal government's involvement in the development of offshore resources; ix) the removal of all refinery taxes to assist the petro-chemical industry; $x$ ) the replacement of PIP grants with a system of taxbased incentives that would assist Canadian companies; $x i)$ removal of the 25 per cent back-in but continuation of the 50 per cent Canadian ownership requirement to the production stage on Canada Lands; and, xii) Petro Canada would be made accountable to Parliament and "act as a private-sector corporation."

49 Pat Carney Papers, Vol. 4 File 12, Newfoundland. Premier Brian Peckford, 1984, Letter Brian Mulroney to Hon. Brian Peckford Premier of Newfoundland, 14 June 1984, 1-6; Vol. 4 File 18, Offshore Resources - Newfoundland, 1984, Letter Ian Anderson to All PC Caucus Members and Staff, 14 June 1984, 1-2. See also, Ibid., "PC Research Briefing Note," 18 June 1984, 1-2.

${ }^{\text {so }}$ Pollard, "Canadian Energy Policy in 1985," 165-66. See also, Doem and Toner, Politics of Energy, 160-61. In addition, British Columbia had taken the issue of offshore mineral rights to the Supreme Court 
in 1967 and lost. For more details on the legalities of the Newfoundland court case and a comparison of Nova Scotia's and Newfoundland's separate agreements with the federal government, see Leo Barry, "Ofishore Petroleum Agreements: An Analysis of the Nova Scotian and Newfoundland Experience," in Managing Natural Resources in a Federal State, ed. J. Owen Saunders (Toronto: Carswell, 1986), 177 89.

"Senator Patricia Carney of British Columbia, interview by author, 26 November 1996, Ottawa, tape recording and transcript, 8.

32 Pat Carney Papers, Vol. 4 File 18, Offshore Resources Newfoundland, 1984, Letter John Crosbie to Pat Carney, 26 June 1984.

"Ibid., Note Brian Mulroney to Pat Carney, 18 June 1984.

"Senator Patricia Camey of British Columbia, interview by author, 26 November 1996, Ottawa, tape recording and transcript, 9.

"Ottawa Citizen, 20 June 1984; Toronto Star, 22 June 1984; Vancouver Province, 18 September 1984.

${ }^{36}$ Montréal Gazette, 27 September 1984.

${ }^{37}$ Pat Carney Papers, Vol. 2 File 8, Energy Policy- Issues - Briefing Book 1983 File 2, Interview Record "Public Affairs International, Harry Near," 27 September 1983; Vol. 4 File 1, Natural Gas -General - 1983-1984 File 1, Letter Harry Near to Pat Carney, 14 December 1983.

so Oilweek, 13 January 1986, 9.

so Ibid.

"Doern and Toner, Politics of Energy, 308. Mickey Cohen had been the deputy minister under Mare Lalonde. When Lalonde moved to the Department of Finance, Cohen went with him. When Jean Chretien took over as energy minister he had appointed Paul Tellier as the deputy minister.

${ }^{61}$ Senator Patricia Carney of British Columbia, telephone interview by author, 19 June 1997, tape recording and transcript, 5 .

${ }^{62}$ NRC, Document 8, "Energy Discussions: An Overview", 13 December 1984, 1-10.

"I Ibid., 9. See also NRC, Document EP 5000-2-2, Memorandum, "Prince Albert Caucus, Progressive Conservative Agenda for Government, Policy Area: Energy," 5 July 1984. The five goals contained in both the "Fundamental Changes to Energy Policy" and the Prince Albert statement were: i) movement to world oil price at the well head and dismantling of the current administered system; ii) market-sensitive pricing for natural gas; iii) flexible border pricing for exports of natural gas; iv) linkage of federal energy taxes to profits, reduction of the tax load on industry to increase 
their cashflow, replace the PGRT, phasing out of PIP and their replace with tax-based incentives; v) Canadianization of the oil industry through replacement of PIP with less rich and less discriminatory incentives, elimination of the retroactive Crown share and introduction of a new Canadian share for oil and gas development. The sixth goal which was not included in the Prince Albert statement was the upgrading of petro-chemical facilities in Ontario and Quebec which was "politically sensitive."

${ }^{6}$ EMR, The Atlantic Accord: Memorandum of Agreement between the Government of Canada and the Government of Newfoundland and Labrador on offshore oil and gas resounce management and revenue sharing (Ottawa: Supply and Services Canada, 1985), 211.

${ }^{65}$ Senator Patricia Carney of British Columbia, telephone interview by author 19 June 1997, tape recording and transcript, 5-6.

${ }^{66}$ Provincial Archives of Alberta (PAA), Energy and Natural Resources (ENR), Acc. 93.337, No Author, "Issue Surrounding Federal/Provincial Negotiations," 26 October 1984. It is not clear who the author of the document was. The significant aspect of the document is that it was in the possession of the Alberta government. ${ }^{7}$ Ibid., 5.

${ }^{6} \mathrm{Ibid}, 2$.

${ }^{6}$ Ibid., Memorandum G.B. Mellon to file, "Meeting of Alberta, B.C., Saskatchewan and Federal Energy Officials, Toronto, November 27, 1984," 30 November 1984, 5-6.

${ }^{70}$ Carney provided some insight in a recent interview. She asserted that the federal officials had no idea what the new PC government wanted and they did not want to admit it. In addition, the bureaucracy did not want to "accept how it was supposed to respond," nor did the bureaucracy completely understand what the minister's office wanted to do. Camey also suggested that the federal officials were not aware of her business background and her familiarity with issues that involved the oil and gas industry. Thus, it was easy for them to dismiss her and say that she did not really know what she was doing as minister of EMR. Senator Patricia Camey of British Columbia, telephone interview by author, 19 June 1997, tape recording and transcript, 6-7. The negative attitude fostered by some federal bureaucrats and perpetuated by the Provincial officials probably made the negotiations more dificult than they needed to be.

"EMR, The Western Accond: AnAgreement between the Governments of Canada, Alberta, Saskatchewan and British Columbia on oil 
and gas pricing and taxation (Ottawa: Supply and Services Canada, 1985), $2-4$.

"Ibid., 2-5. Specific examples of recommendations that were included in the final agreement were: the force majeure clause (in case of emergency to protect Canadian interests); free negotiations between buyers and sellers; market sensitive pricing for natural gas; taxation on basis of profits rather than revenues; phasing out of PGRT; elimination of all other NEP taxes; small producer credit, transferable from year to year; tax-based incentives; and the assurance that revenues would be transferred through to the industry without the provinces taking a portion of the money. Pat Carney Papers, Vol. 1 File 24, Energy - briefing book on oil and gas programs [Mar.] 1984 File 1, IPAC Task Foroe Report "IPACEnergy Policy Discussion Paper," $3,4,6$.

${ }^{73}$ Ibid.

"Edmonton Joumal, 29 March 1985. In the same article it states that the Westem Accord "was clearly good news to the industry, which generally praised the deal."

${ }^{75}$ EMR, Canada's Energy Frontiers: A Framework for Investment and Jobs (Ottawa: Supply and Services Canada, 1985), 5-19. Pat Carney Papers, Vol. 1 File 24, Energy - briefing book on oil and gas programs [Mar.] 1984 File 1, COGLA study group Report, "Task Force Comments and Recommendations," 4-10; PIP study group Report "Petroleum Incentives Program," 10, 12.

${ }^{76} \mathrm{Ibid}$.

"EMR, Agreement on Natural Gas Markets and Prices (Ottawa: Supply and Services Canada, 1985), 1-5.

${ }^{78}$ Edmonton Journal, 31 October 1985.

${ }^{79}$ Toronto Star, 1 November 1985.

${ }^{80}$ Toronto Star , 2 November 1985.

81 Ibid.

${ }^{82}$ PAA, ENR, Acc. 93.337, Memorandum from Luigi Di Marzo to N.E. MacMurchy, 9 October 1984, "Position of Consuming Provinces Re a New Energy Policy." In this memo Carney is mentioned as meeting with both Ontario and Quebec in order to keep a dialogue open between all vested interests.

${ }^{83}$ PAA, ENR, Acc. 93.337, Memorandum from Luigi Di Marzo to File, 5 December 1984, "Meeting With Officials in Ontario Energy Department, Nov. 28, 1984," 5. Duncan Allen was the deputy energy minister for Ontario at this time.

${ }^{4}$ Vancouver Sun, 16 November 1985.

${ }^{\text {ss }}$ Ibid. 


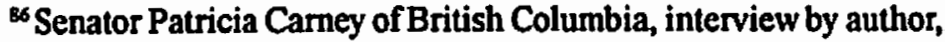
Ottawa, 26 November 1996, tape recording and transcript, 8. ${ }^{87}$ Ibid., 9.

"As Toner comments: "[The study group recommendations] reinforced Carney's personal belief - which she has been vigorously championing now for at least fifteen years - that energy development can be a major 'engine of economic growth.' The Tory energy program can basically be understood as a manifestation of this conception of the potential of the private sector." See "Stardust," 123.

${ }^{\text {99 }}$ Senator Patricia Carney of British Columbia, interview by author, Ottawa, 26 November 1996, tape recording and transcript, 3; Senator Patricia Carney of British Columbia, telephone interview by author, 19 June 1997, tape recording and transcript, 7.

${ }^{90}$ Bercuson, Granatstein, and Young, Sacred Trust?, 99-105. For Mulroney's statement of Canada's social welfare system being a "sacred trust," see 94. Among other PC MPs who were not able to implement the policy that was developed while in opposition were: Marcel Masse, minister of communications; Jake Epp, minister of health and welfare; and to some extent Don Mazankowski, minister of transportation. Mazankowski did not privatize Air Canada but he did guide the privatization of the de Havilland aircraft company and did manage to deregulate some aspects of the transportation sector, 130-31. "[Masse] cast aside the cultural policies that had been developed by the Conservatives in opposition and floundered around to find replacements. . . . Naturally, he relied on the bureaucrats who were closest to him. .. ," 202.

${ }^{91}$ For instance, "Canada is already a signatory to an International Floor Price of $\$ 7$ (U.S.) per barrel through its membership in the International Energy Agency." Toner, "Stardust," 141. 